\title{
AKUISISI FOREGROUND DAN BACKGROUND BERBASIS FITUR DCT PADA MATTING CITRA SECARA OTOMATIS
}

\author{
Meidya Koeshardianto*1, Eko Mulyanto Yuniarno², Mochamad Hariadi \\ ${ }^{1}$ Jurusan Teknik Informatika, Fakultas Teknik, Universitas Trunojoyo Madura \\ ${ }^{2,3}$ Departemen Teknik Elektro, Fakultas Teknologi Elektro, Institut Teknologi Sepuluh Nopember Surabaya \\ Email: ${ }^{1}$ meidya@trunojoyo.ac.id, ${ }^{2}$ ekomulyanto@ee.its.ac.id, ${ }^{3}$ mochar@ee.its.ac.id \\ *Penulis Korespondensi
}

(Naskah masuk: 10 Juli 2019, diterima untuk diterbitkan: 27 April 2020)

\begin{abstract}
Abstrak
Teknik pemisahan foreground dari background pada citra statis merupakan penelitian yang sangat diperlukan dalam computer vision. Teknik yang sering digunakan adalah image segmentation, namun hasil ekstraksinya masih kurang akurat. Image matting menjadi salah satu solusi untuk memperbaiki hasil dari image segmentation. Pada metode supervised, image matting membutuhkan scribbles atau trimap sebagai constraint yang berfungsi untuk melabeli daerah tersebut adalah foreground atau background. Pada makalah ini dibangun metode unsupervised dengan mengakuisisi foreground dan background sebagai constraint secara otomatis. Akuisisi background ditentukan dari varian nilai fitur DCT (Discrete Cosinus Transform) yang dikelompokkan menggunakan algoritme $k$-means. Untuk mengakuisisi foreground ditentukan dari subset hasil klaster fitur DCT dengan fitur edge detection. Hasil dari proses akuisisi foreground dan background tersebut dijadikan sebagai constraint. Perbedaan hasil dari penelitian diukur menggunakan MAE (Mean Absolute Error) dibandingkan dengan metode supervised matting maupun dengan metode unsupervised matting lainnya. Skor MAE dari hasil eksperimen menunjukkan bahwa nilai alpha matte yang dihasilkan mempunyai perbedaan 0,0336 serta selisih waktu proses 0,4 detik dibandingkan metode supervised matting. Seluruh data citra berasal dari citra yang telah digunakan para peneliti sebelumnya.
\end{abstract}

Kata kunci: Image segmenterasi, image matting, fitur DCT, deteksi tepi, scribbles

\section{FOREGROUND AND BACKGROUND ACUISITION FOR AUTOMATIC IMAGE MATTING BASED ON DCT FEATURE}

\begin{abstract}
The technique of separating the foreground and the background from a still image is widely used in computer vision. Current research in this technique is image segmentation. However, the result of its extraction is considered inaccurate. Furthermore, image matting is one solution to improve the effect of image segmentation. Mostly, the matting process used scribbles or trimap as a constraint, which is done manually as called a supervised method. The contribution offered in this paper lies in the acquisition of foreground and background that will be used to build constraints automatically. Background acquisition is determined from the variant value of the DCT feature that is clustered using the k-means algorithm. Foreground acquisition is determined by a subset resulting from clustering DCT values with edge detection features. The results of the two stages will be used as an automatic constraint method. The success of the proposed method, the constraint will be used in the supervised matting method. The difference in results from In the research experiment was measured using MAE (Mean Absolute Error) compared with the supervised matting method and with other unsupervised matting methods. The MAE score from the experimental results shows that the alpha matte value produced has a difference of 0.336 , and the difference in processing time is 0.4 seconds compared to the supervised matting method. All image data comes from images that have been used by previous researchers.
\end{abstract}

Keywords: image segmentation, image matting, DCT feature, Laplacian matting

\section{PENDAHULUAN}

Proses pemisahan obyek foreground dan background pada sebuah citra merupakan teknik yang sangat diperlukan dalam bidang multimedia khususnya pembuatan visual efek film animasi. Image segmentation merupakan salah satu teknik 
yang sering digunakan. Namun, ektraksi foreground dan background yang dihasilkannya belum dapat memisahkan obyek foreground secara akurat. Beberapa pendekatan metode ekstraksi dilakukan salah satunya menggunakan image matting, diperkenalkan sebagai solusi untuk memperbaiki hasil ekstraksi yang dilakukan pada image segmentation.

Perkembangan image matting diawali dengan penggunaan trimap dan scribbles atau dikenal sebagai constraint dengan mengasumsikan warna hijau atau biru sebagai background pada sebuah citra. Teknik ini biasa dikenal dengan teknik green screen matting atau blue screen matting. Namun, beberapa permasalahan ditemui saat penggunaan teknik green screen matting diimplementasikan. Permasalahannya adalah dibutuhkannya layar yang relatif besar serta sistem pencahayaan yang ideal. Untuk mengatasi permasalahan tersebut diperkenalkan Natural image matting.

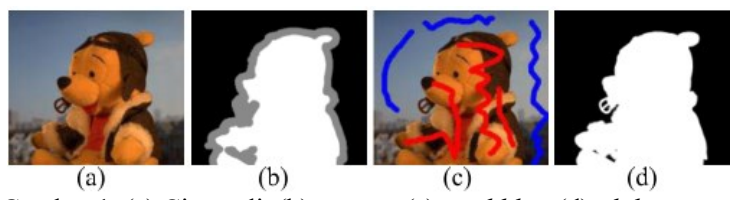

Gambar 1. (a) Citra asli. (b) trimap. (c) scribbles. (d) alpha matte. (Zhu et al., 2015)

Pendekatan natural image matting dilakukan dengan dua cara, yakni: terbimbing (supervised) dimana membutuhkan constraint dan tidak terbimbing (unsupervised) atau secara otomatis. Pada Gambar 1(b), constraint dibentuk dengan melabeli hampir seluruh daerah citra dengan nilai 0 sebagai background dan nilai 1 sebagai foreground atau dikenal dengan trimap. Sisanya adalah daerah yang belum diketahui nilainya. Gambar 1(c) adalah constraint berupa scribbles dimana hanya memberikan sebagian label pada daerah citra. Seluruh constraint ditentukan secara manual sehingga mempunyai kelebihan dapat menentukan foreground dan background secara akurat artinya sesuai dengan asumsi. Namun kelemahannya dibutuhkan usaha lebih untuk melabeli daerah foreground dan background.

Sangat berbeda dengan supervised matting, pada metode unsupervised proses matting dapat dilakukan tanpa memberikan label pada sebagian daerah foreground dan background. Dampaknya adalah proses matting dapat dilakukan tanpa harus membangun constraint sehingga dapat mengurangi kompleksitas pengguna. Meskipun dapat dilakukan secara otomatis, dalam beberapa kasus teknik supervised mempunyai kelemahan dalam menghasilkan ekstraksi yang sesuai asumsi pengguna mengenai foreground dan background.

Pada penelitian kali ini diperkenalkan metode automatic image matting dengan mengakuisisi foreground dan background sebagai constraint secara otomatis. Proses pembentukan constraint dilakukan dua tahap yakni akuisisi background dan foreground. Akuisisi backround dilakukan dengan jalan mendeteksi besaran varian dari fitur yang dihasilkan oleh Discrete Cosinus Transform (DCT). Hasil dari fitur DCT selanjutnya dilakukan proses klaster menggunakan $k$-means. Untuk akuisisi foreground, ditentukan dengan metode edge detection. Hasil dari akuisisi foreground ditentukan oleh daerah klaster background yang bukan merupakan subset pada edge detection. Hasil kedua proses tersebut digunakan sebagai constraint pada supervised matting. Dengan demikian, keterbaruan dari penelitian ini adalah membuat metode supervised matting menjadi unsupervised matting dengan mengakuisisi foreground dan background sebagai constraint secara ototmatis.

\section{PERMASALAHAN IMAGE MATTING}

Image matting dan image segmentation merupakan dua metode yang digunakan untuk memisahkan obyek foreground dari citra. Ada perbedaan yang sangat mendasar antara kedua metode ini yakni alpha matte yang dihasilkan dari kedua metode tersebut. Untuk image segmentation, alpha matte yang dihasilkan bernilai 0 dan 1 . Berbeda dengan metode matting, alpha matte yang dihasilkan bernilai antara 0 dan 1. Sehingga ekstraksi yang dihasilkan lebih detail. Perbedaan dapat dilihat pada Gambar.2(b) menampilkan perbedaan alpha matte dari metode image segmentation dengan image matting.

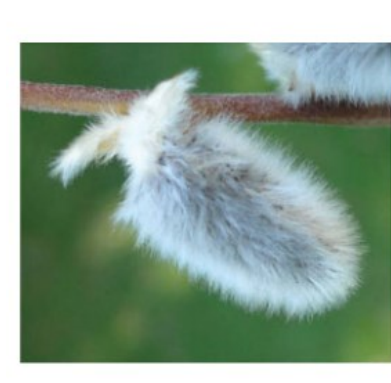

(a)

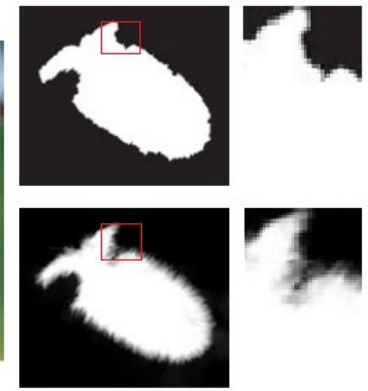

(b)
Gambar.2 Perbandingan hasil alpha matte. (a) Citra asli. (b, atas) Ekstraksi menggunakan metode segmentasi. (b, bawah) Ekstraksi menggunakan metode matting (Wang and Cohen, 2007)

Namun demikian, bukan berarti image segmentation telah ditinggalkan oleh para peneliti, dalam beberapa hal image segmentation masih digunakan sebagai preprocessing di bidang pengenalan wajah dan sidik jari serta identifikasi citra lainnya. Bahkan dalam image matting, proses image segmentation tetap dapat digunakan untuk membangun constraint yakni sebagai trimap.

Image matting pertama kali diperkenalkan oleh (Porter and Duff, 1984) dengan model persamaan:

$I_{i}=\alpha_{i} F_{i}+\left(1-\alpha_{i}\right) B_{i}$ 
dimana sebuah citra $I$ terletak pada posisi $i$ merupakan vektor dari masing - masing warna RGB (red, green, blue) yang bercampur sehingga nilai alpha matte $\alpha$ relatif proporsional terhadap nilai foreground $\mathrm{F}$ dan background $\mathrm{B}$. Nilai $\alpha$ mendekati 0 maka piksel tersebut dapat dipastikan sebagai background demikian juga sebaliknya apabila nilai $\alpha$ mendekati 1 maka dapat dipastikan bahwa piksel tersebut adalah foreground. Hasil akhir dari proses matting pada sebuah citra $I$ adalah citra foreground $\boldsymbol{F}$, background $\boldsymbol{B}$ dan nilai alpha matte $\boldsymbol{\alpha}$.

Diawal makalah telah dijelaskan, untuk mempermudah proses matting digunakanlah blue screen matting (Smith and Blinn, 1996). Hal ini bertujuan untuk mengurangi variabel yang harus dicari. Persamaan (1) menghasilkan tujuh variabel yang harus diketahui dalam menyelesaikan proses matting yakni $\alpha, F^{c}$ dan $B^{c}$ dimana $c \in\{R, G, B\}$. Dengan menggunakan metode blue screen matting, maka komponen warna biru pada citra dapat dieliminasi sehingga berdasarkan persamaan (1) tersisa tiga variabel yang belum diketahui yakni $\alpha, F^{R}$ dan $F^{G}$. Penyelesaian sisa variabel yang belum diketahui dapat diselesaikan menjadi:

$\alpha=I^{B}-B^{B}, I^{R}=\alpha F^{R}, I^{G}=\alpha F^{G}$

Persamaan (2) atau metode blue screen matting masih digunakan sebagai pembentuk citra ground truth pada image matting.

Untuk saat ini, penelitian image matting dititikberatkan pada metode natural image matting. Pada metode natural image matting telah berkembang menjadi dua yakni supervised dan unsupervised.

Dalam metode supervised, scribbles digunakan pada metode affinity based matting (Levin, Lischinski and Weiss, 2008) untuk menyelesaikan alpha matte. Variasi affinity didefinisikan sebagai nilai bobot pembentuk alpha matte. Penggunaan metode poisson (Sun et al., 2004) digunakan mengestimasi nilai alpha matte. Untuk mengurangi kompleksitas dilakukan modifikasi gradien secara otomatis dan interaktif berdasarkan intensitas (Grady et al., 2005) perubahan baik pada foreground dan backgorund.

Perkembangan metode supervised selanjutnya didekati dengan penggunaan constraint secara otomatis menggunakan trimap (Vicas et al., 2013; Shen et al., 2016; Cho et al., 2017). Convolutional Neural Network (CNN) (Shen et al., 2016) digunakan untuk mendefinisikan komponen constraint pada matting. Dalam (Cho et al., 2017), image matting digunakan sebagai pengenalan obyek dengan memodifikasi klaster geometrik untuk menentukan foreground dan background sebagai trimap. Teknik segmentasi digunakan sebagai awal dari pembentukan trimap. Kontur hasil dari image segmentation diasumsikan sebagai inisialisasi. Selanjutnya struktur foreground dianalisa sehingga terbentuk constraint secara otomatis. Pembentukan constraint juga dilakukan menggunakan teknik registrasi pada citra menggunakan SIFT (Koeshardianto, 2016) untuk membangun constraint secara otomatis.

Metode unsupervised matting pertama kali diperkenalkan (Levin, Rav-acha and Lischinski, 2008) dengan metode spectral matting. Akuisisi background dan foreground ditentukan melalui besaran nilai eigen kemudian diimplementasikan pada video (Eisemann, Wolf and Magnor, 2009). Ekstraksi obyek dengan jalan membentuk citra dalam dua atau lebih segmen dimana setiap segmen adalah kumpulan dari varian piksel yang homogen atau dikenal dengan layer. Dari pembentukan layer tersebut beberapa metode menggunakannya sebagai dasar melakukan soft segmentation menggunakan global optimisasi (Tan et al., 2013), ekstraksi warna per piksel (Aksoy et al., 2018).

Dengan berkembangnya metode unsupervised matting, terjadi pergeseran topik penelitian yang dihadapi khususnya di bidang animasi film, teknik Rotoscoping juga melakukan hal yang sama yakni memisahkan foreground dan background secara interaktif ( $\mathrm{Lu}$ et al., 2016). Rotoscoping menggunakan teknik Roto++ (Li et al., 2016) merupakan proses soft segmentation obyek foreground dan background dalam video. Untuk mempermudah proses tersebut, dikembangkan teknik ROAM (Miksik et al., 2017) yang merupakan pengembangan Grab-Cut (Rother, Kolmogorov and Blake, 2004). Segmentasi menggunakan constraned berdasarkan lokasi, skala serta model dari target digunakan (Long, Liu and Han, 2017) untuk memisahkan obyek dari video. Menggunakan video segmentation, (Mashtalir and Mashtalir, 2016) menterjemahkan low-level fitur pada video agar mudah dimengerti oleh pengguna. (Zeng et al., 2017) menggunakan Fuzzy partiotion untuk mengekstrak obyek hasil dari dynamic background subtraction.

Penelitian mengenai ekstraksi obyek dari video masih terus berkembang hingga saat ini. Background subtraction, video segmentation, rotoscoping merupakan sebagian teknik untuk memisahkan obyek dari video dan pada penelitian yang berkembang saat ini telah dilakukan secara otomatis. Dengan berbagai permasalahan serta trend penelitian tersebut, dalam makalah ini dibahas tentang automatic image matting sehingga dapat diimplementasikan pada video.

\section{LAPLACIAN MATTING}

Berdasarkan persamaan (1), setiap warna pada posisi ke $i$ terurai menjadi dua layer yakni foreground dan background secara linear. Dengan menggunakan fungsi linear, $\alpha$ dapat ditulis menjadi:

$\alpha_{i} \approx a I+b, \forall i \in w$ 
Dimana $a=\frac{1}{F-B}$, dan $b=-\frac{B}{F-B}$ dan $w$ adalah blok piksel. Dengan mencari nilai minimum dari cost function, maka koefisien $a, b$ dan $\alpha$ dapat diestimasi menjadi:

$J(\alpha, a, b)=\sum_{j \in i}\left(\sum_{i \in w_{j}}\left(\alpha_{i}-a_{j}-b_{j}\right)^{2}+\epsilon a_{j}^{2}\right)$

dimana $w_{j}$ adalah blok piksel disekitar $j$ dan $\epsilon$ merupakan konstanta sebagai regularisasi pada $a_{j}$.

Selanjutnya, ukuran blok piksel sebesar $3 \times 3$ digunakan saat implementasi untuk mendeteksi propagasi intensitas antar piksel tetangga. Menggunakan teorema (1) pada (Levin, Lischinski and Weiss, 2008), $a_{j}$ dan $b_{j}$ dapat dieliminasi dari persamaan (4) untuk mendapatkan sebuah cost function yang tergantung hanya pada $\alpha$ menjadi:

$J(\alpha)=\alpha^{T} L \alpha$

Variabel $\alpha$ merupakan vektor berukuran $\mathrm{N} \times 1$ dan L adalah matrik Laplacian berukuran $\mathrm{N} \times \mathrm{N}$ sehingga nilai pada posisi $(i, j)$ dapat didefinisikan menjadi:

$L_{i j}=\sum_{k \mid(i, j) \in w_{k}}\left(\delta_{i j}-\frac{1}{\left|w_{k}\right|}\left(1+\frac{1}{\frac{\epsilon}{\left|w_{k}\right|}+\sigma_{k}^{2}}\left(I_{i}-\mu_{k}\right)\left(I_{j}-\mu_{k}\right)\right)\right.$

Variabel $\mathrm{N}$ adalah jumlah piksel sebagai obyek target, $\delta_{i j}$ adalah kronecker delta. Sedangkan $\mu_{k}$ dan $\sigma_{k}^{2}$ adalah mean dan intensitas varian pada blok piksel $w_{k}$. Untuk $\left|w_{k}\right|$ adalah jumlah piksel pada blok $w_{k}$. Sehingga alpha matte dapat diselesaikan dengan:

$\alpha=\operatorname{argmin} \alpha^{T} L \alpha+\lambda\left(\alpha^{T}-b_{s}^{T}\right) D_{s}\left(\alpha-b_{s}\right)$

Dimana $\lambda$ adalah konstanta dengan nilai yang besar, $D_{s}$ adalah diagonal matrik dengan nilai 1 untuk piksel constraint dan 0 untuk piksel yang lainnya. Untuk $b_{s}$ merupakan constraint dimana terdiri atas nilai spesifik alpha. Dalam sistem linear, variabel $\alpha$ pada persamaan (7) dapat ditulis menjadi:

$\left(L+\lambda D_{s}\right) \alpha=\lambda b_{s}$

Dalam metode supervised, $b_{s}$ ditentukan secara manual atau dalam image matting dikenal dengan scribbles. Dalam penelitian ini, persamaan (8) digunakan sebagai formula proses matting. Variabel $b_{s}$ didekati dengan mengakuisisi foreground dan background sebagai scribbles serta dilakukan secara otomatis.

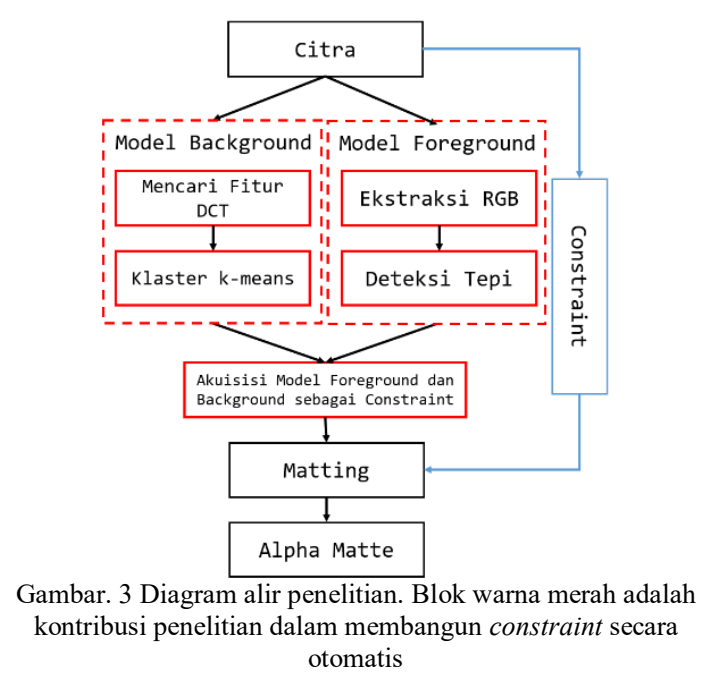

\section{METODOLOGI AKUISISI FOREGROUND DAN BACKGROUND}

Akuisisi atau proses mendefinisikan foreground dan background digunakan untuk membangun constraint pada image matting. Diagram alir pada Gambar. 3 memperlihatkan tahapan penelitian yang akan dilakukan yakni: membangun model background dan model foreground. Langkah selanjutnya adalah mengakuisisi dari kedua model yang telah dibangun. Garis warna biru pada Gambar. 3 adalah proses yang dilakukan secara manual yakni constraint ditentukan oleh pengguna sebelum proses matting dilakukan.

\subsection{Model Background}

Ekstraksi Fitur: DCT dipilih karena pada prosesnya tidak memerlukan memory besar serta penentuan fitur dapat dilakukan dengan cara relatif mudah. Secara prinsip DCT melakukan hal yang sama dengan metode sejenis seperti Fourier Transform yakni menggunakan fungsi basis sinusoidal. Perbedaannya ada pada penerapan fungsi basis DCT dimana hanya menggunakan fungsi kosinus tanpa melibatkan fungsi sinus. Penentuan fitur didapatkan dari nilai kosinus tertinggi hasil DCT pada sebuah blok piksel tetangga. Besaran blok piksel tetangga dimulai dari $3 \times 3$ namun untuk lebih detail penjelasan dilakukan pada eksperimen di bab V. Untuk persamaan DCT 2 dimensi pada sebuah citra berukuran $N \times M$ dapat ditulis:

$C(u, v)=\frac{2}{\sqrt{M N}} \alpha(u) \alpha(v) K$

dimana nilai $\mathrm{K}$ didapat dari:

$K=\sum_{x=0}^{N-1} \sum_{y=0}^{M-1} f(x, y) \cos \left[\frac{(2 x+1) \pi u}{2 N}\right] \cos \left[\frac{(2 x+1) \pi v}{2 M}\right]$

untuk $u \in\{1,2 . . N-1\}$ dan $v \in\{1,2 . . M-1\}$. Fitur yang akan dipakai didapatkan dari nilai terbesar 
hasil DCT untuk mewakili fitur dari blok tetangga piksel.

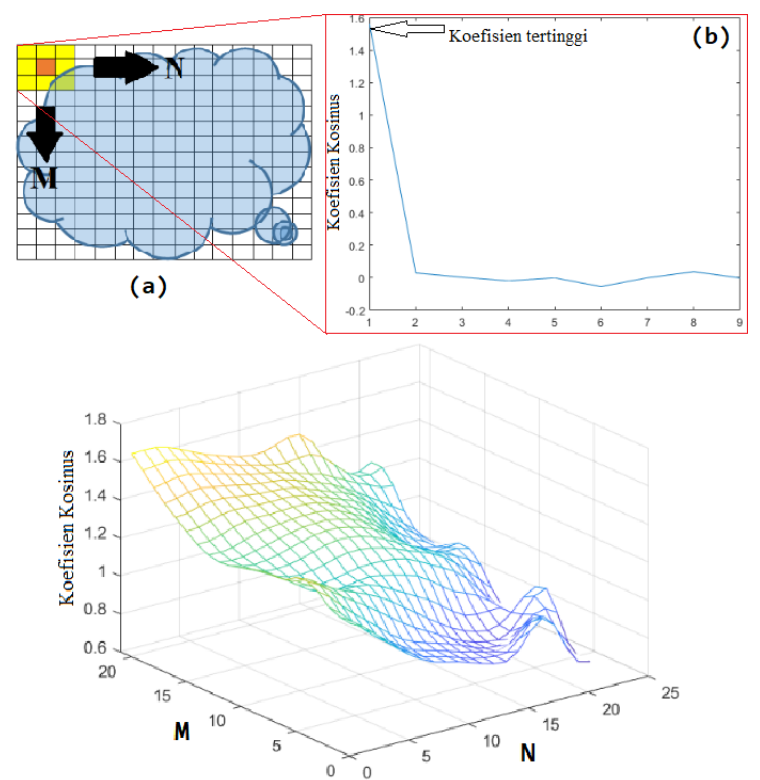

(c)

Gambar. 4 Ilustrasi proses pembentukan fitur DCT. (a) Contoh citra yang akan diproses. (b) Hasil ekstraksi fitur DCT dari 1 blok citra. (c) Hasil seluruh fitur dari citra dengan mengambil koefisien kosinus tertinggi.

Diberikan data citra Gambar. 4(a), maka fitur DCT didapat dari hasil satu blok piksel tetangga sejumlah $(M-1)(N-1)$. Hasil fitur DCT diambil nilai kosinus tertinggi, dalam hal ini DCT menghasilkan kosinus tertinggi pada index yang pertama seperti terlihat pada Gambar. 4(b). Seluruh fitur pada data citra akan tampak seperti pada Gambar. 4(c).

Clustering: Hasil dari fitur DCT selanjutnya dilakukan proses klaster menggunakan $k$-means. Hasil akhir model background ditentukan berdasarkan hasil klaster yang bukan merupakan subset foreground. Sehingga, apabila terdapat klaster $C_{1}, \cdots, C_{n}$ dimana $n$ adalah jumlah klaster pada $k$ means, maka model background $B_{s}$ dapat ditulis:

$B_{s}=C_{n} \rightarrow n \notin F_{s}$

dimana $F_{S}$ adalah model foreground.

\subsection{Model Foreground}

Model foreground didapatkan dari hasil proses diferensial pada citra. Hasil yang didapatkan adalah perubahan intensitas tiap piksel pada citra. Apabila dinotasikan $\nabla I^{c}$ sebagai gradien dari citra, maka diferensial pertama dari citra dapat dituliskan:

$\nabla I^{c}=\left[\begin{array}{l}\frac{\partial I^{c}}{\partial x} \\ \frac{\partial I^{c}}{\partial y}\end{array}\right]=\left[\begin{array}{l}F_{h}^{c} \\ F_{v}^{c}\end{array}\right]$ dimana $\nabla F_{h}^{c}$ dan $\nabla F_{v}^{c}$ adalah gradient vektor dari horizontal dan vertikal. Atau dapat dijabarkan menjadi:

$$
\begin{aligned}
& \nabla F_{h}^{c}=\left[\begin{array}{lll}
\frac{\partial R}{\partial x} & \frac{\partial G}{\partial x} & \frac{\partial B}{\partial x}
\end{array}\right] \\
& \nabla F_{v}^{c}=\left[\begin{array}{lll}
\frac{\partial R}{\partial y} & \frac{\partial G}{\partial y} & \frac{\partial B}{\partial y}
\end{array}\right]
\end{aligned}
$$

Selanjutnya, mean $\mu_{i}^{c}$ dicari dari setiap gradien pada persamaan (11) sebagai filter noise (salt dan paper). Setelah mendapatkan nilai mean serta proses thresholding, model foreground $F_{S}$ dan dapat ditulis menjadi:

$F_{s}=\left\{\begin{array}{c}1, j i k a\left(\nabla F_{h}^{c}-\mu_{x}^{c}\right)+\left(\nabla F_{v}^{c}-\mu_{y}^{c}\right)>\tau \\ 0, \text { lainnya }\end{array}\right.$

dimana $\tau$ adalah besaran threshold

Persamaan (12) berbeda dengan metode fitur edge detection pada umumnya. Proses penentuan fitur edge dilakukan berdasarkan tiap layer warna (RGB) dengan melakukan proses background subtraction terhadap nilai mean. Pada Gambar. 5 menampilkan perbedaan algoritma edge yang hasil dari persamaan (12) dengan algoritma sobel dan prewitt.

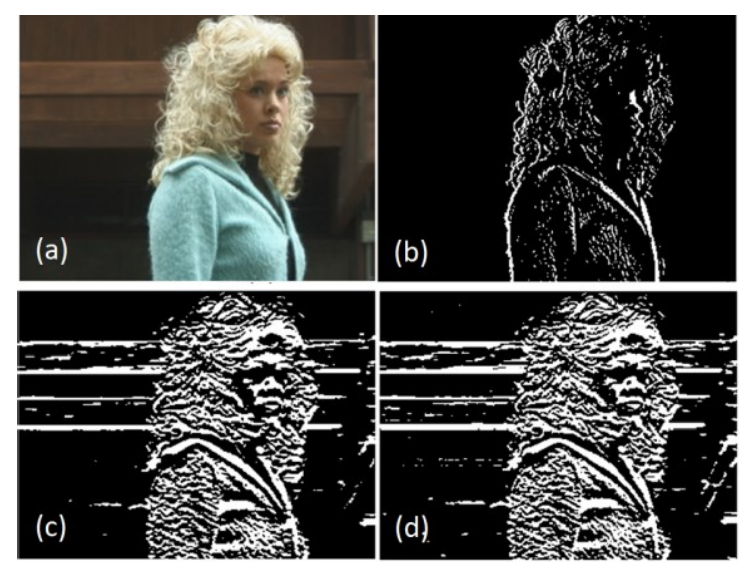

Gambar. 5 Perbandingan hasil proses edge detection dari beberapa metode. (a) Citra asli. (b) Hasil dari penelitian yang dilakukan. (c) Hasil menggunakan metode prewitt. (d) Hasil menggunakan metode sobel.

Setelah mengakuisisi kedua model baik background dan foreground, selanjutnya persamaan (11) dan persamaan (12) disubtitusikan ke dalam variabel $b_{s}$ pada persamaan (8) menjadi:

$\left(L+\lambda D_{s}\right) \alpha=\lambda\left(F_{s}+B_{S}\right)$

Oleh karena akuisisi foreground $F_{S}$ dan background $B_{S}$ didapat secara otomatis, maka perubahan yang sangat mendasar dari penelitian yang dilakukan adalah merubah metode yang awalnya supervised menjadi unsupervised. 
552 Jurnal Teknologi Informasi dan Ilmu Komputer (JTIIK), Vol. 7, No. 3, Juni 2020, hlm. 547-554

\section{HASIL EKSPERIMEN}

Pada bab ini akan ditampilkan beberapa hasil dari eksperimen yang telah dilakukan. Seluruh data eksperimen yang digunakan berasal dari data citra yang telah dipakai pada peneliti (Levin, Lischinski and Weiss, 2008). Seluruh eksperimen diproses dan dijalankan pada Intel ${ }^{(\mathrm{R})} \mathrm{Core}^{(\mathrm{TM})}$ i5-8250U @1,6GHz dengan RAM 8GB dan VGA NVIDIA GeForce 940MX (8GB).
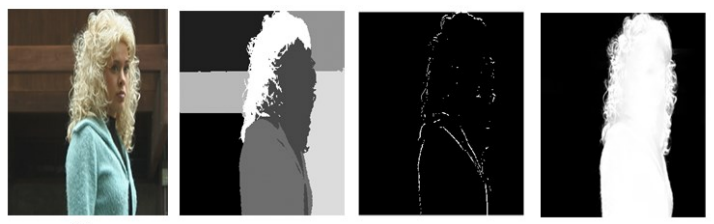

Kim
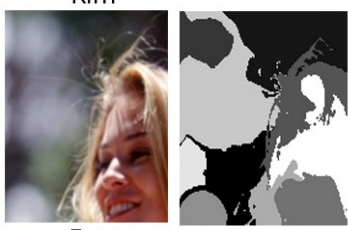

Face
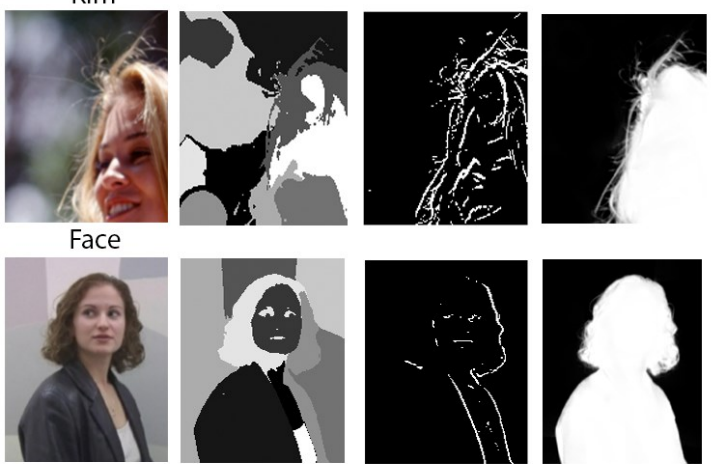

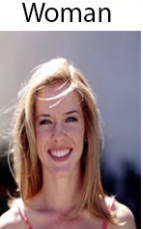

Wind

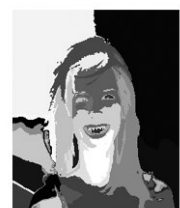

(a)

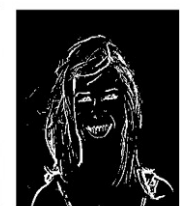

(b)

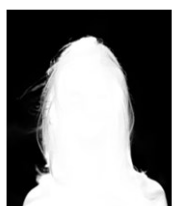

(c)
Gambar. 6 Hasil penelitian yang telah dilakukan. (b) Akuisisi background. (b) Hasil akuisisi foreground. (c) Hasil alpha matte.

Hasil dari akuisisi foreground dan background secara keseluruhan ditampilkan seperti pada Gambar. 6 data citra Kim, Face, Woman dan Wind dapat menghasilkan alpha matte menggunakan constraint yang telah dibangun. Beberapa nilai parameter dalam eksperiman ditentukan untuk mendapatkan alpha matte terbaik yakni jumlah klaster pada $k$-means pada data citra Kim sebesar 8, data citra Face membutuhkan jumlah klaster 10, untuk Woman dan Wind berturut - turut membutuhkan jumlah klaster 10 dan 40.

Dalam skenario selanjutnya, dilakukan perbandingan kecepatan proses dari metode yang telah dibuat dengan metode closed-form matting (Levin, Lischinski and Weiss, 2008) dan spectral matting (Levin, Rav-acha and Lischinski, 2008) seperti yang diperlihatkan pada Table 1 .

Selanjutnya, eksperimen yang dilakukan adalah membandingkan akurasi hasil alpha matte dari metode yang digunakan dengan alpha matte pada kedua metode sebelumnya. Ground Truth yang dipakai merupakan hasil alpha matte dari metode supervised.
Tabel 1. Perbandingan kecepatan proses

\begin{tabular}{lccc}
\hline $\begin{array}{l}\text { Data Citra } \\
\text { (Dimensi) }\end{array}$ & \multicolumn{3}{c}{ Waktu yang diperlukan (dalam detik) } \\
\cline { 2 - 4 } & Spectral & $\begin{array}{c}\text { Closed } \\
\text { Form }\end{array}$ & $\begin{array}{c}\text { Metode yang } \\
\text { diusulkan }\end{array}$ \\
\hline $\begin{array}{l}\text { Kim } \\
(238 \times \text { x 318) }\end{array}$ & 70,5366 & 6,8906 & 7,3321 \\
$\begin{array}{l}\text { Face } \\
(165 \times 137)\end{array}$ & 25,9910 & 5,2498 & 5,3469 \\
$\begin{array}{l}\text { Woman } \\
(212 \times 165)\end{array}$ & 35,9130 & 8,0105 & 8,1338 \\
$\begin{array}{l}\text { Wind } \\
(254 \times 254)\end{array}$ & 113,1572 & 7,4317 & 7,9143 \\
\hline
\end{tabular}

Pengukuran akurasi menggunakan MAE seperti halnya yang dilakukan pada (Zhang et al., 2015) dan (Cho et al., 2016). Persamaan MAE dapat dituliskan dengan:

$M A E=\frac{1}{M N} \sum_{x=1}^{N} \sum_{y=1}^{M}|\alpha(x, y)-\bar{\alpha}(x, y)|$

dimana $\bar{\alpha}$ adalah alpha matte diperoleh dari metode Closed Form Matting (Levin, Lischinski and Weiss, 2008).

Pada Gambar. 7 ditampilkan perbandingan secara quantitative menggunakan MAE. Hasil terbaik menghasilkan nilai MAE minimum.
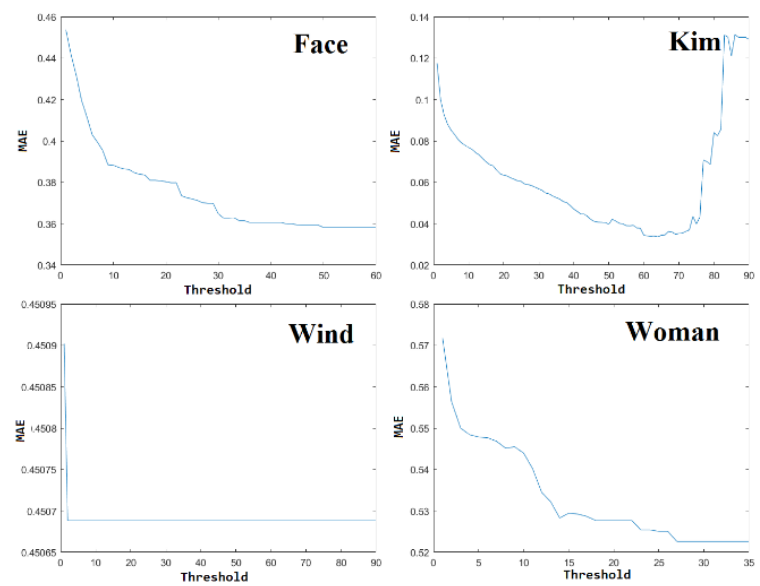

Gambar. 7 Perbandingan Quantitative: Nilai MAE perbandingan alpha matte antara metode yang diusulkan dengan metode Closed Form.

\section{ANALISA EKSPERIMEN}

\subsection{Analisa Akuisisi Model}

Dalam akuisisi background, beberapa hal yang sangat berpengaruh terhadap hasil eksperimen yaitu penentuan jumlah blok tetangga dan jumlah klaster. Dimensi dari citra yang akan diproses dipengaruhi dari penentuan jumlah blok tetangga. Semakin besar blok tetangga maka semakin besar pula dimensi citra yang akan diproses berkurang. Apabila jumlah blok tetangga diberikan nilai 1 , maka dimensi citra akan berkurang menjadi $\mathrm{N}-2$ dan $\mathrm{M}-2$ karena posisi pencarian fitur DCT dimulai dari $\mathrm{x}+1$ sampai $\mathrm{N}-1$ dan $\mathrm{y}+1$ sampai M-1. 


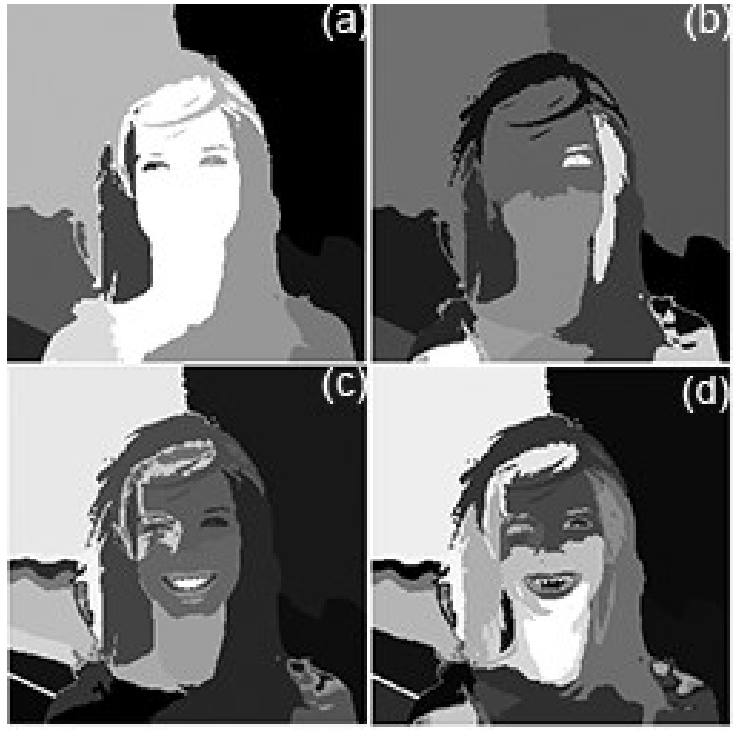

Gambar. 8 Hasil klaster menggunakan $k$-means dari citra Wind. (a) Hasil $k$-means dengan kluster 10. (b) Hasil $k$-means dengan kluster 20. (c) Hasil k-means dengan kluster 30. (d) Hasil $k$-means dengan kluster 10 .

Selanjutnya, pengaruh dari jumlah klaster pada tiap data yang diproses berpengaruh terhadap hasil matting. Proses klaster dalam penelitian ini berfungsi untuk membantu mengakuisisi foreground dan background. Karena selain hasil dari klaster foreground masih ditentukan oleh subset dari hasil deteksi tepi. Sebagai contoh pada Gambar. 8(a), menunjukkan proses klaster menghasilkan daerah foreground menjadi satu dengan daerah background pada tempat yang sama. Hal yang sama juga terlihat pada Gambar. 8(b) dan (c) yakni masih ada klaster daerah foreground yang masih menjadi satu dengan daerah background.

Demikian juga dengan nilai threshold pada proses deteksi tepi sangat berpengaruh terhadap hasil matting. Penentuan nilai parameter jumlah klaster dan threshold menjadi krusial untuk menghasilkan alpha matte yang diinginkan. Penelitian ini masih sangat memungkinkan untuk dilanjutkan salah satunya dalam penentuan parameter secara robust. Sehingga proses pemilihan nilai parameter baik klaster maupun threshold dapat dilakukan juga secara lebih efisien.

\subsection{Analisa Akurasi dan Kecepatan}

Dalam hal kecepatan, nilai perbandingan antara metode penelitian yang dilakukan dengan metode supervised tidak jauh berbeda. Perbandingan selisih waktunya tidak lebih dari satu detik. Perbandingan dengan metode supervised sangat penting dalam penelitian karena menunjukkan bahwa dengan selisih waktu kurang dari satu detik, metode yang dilakukan dapat mengurangi usaha lebih dalam memberikan label secara manual.

Namun tidak demikian apabila dibandingkan dengan metode unsupervised dimana menghasilkan perbandingan kecepatan yang jauh berbeda. Hal ini disebabkan metode unsupervised membutuhkan memory yang cukup besar sehingga membutuhkan waktu yang lebih lama dalam prosesnya. Apabila dibandingkan dengan metode supervised, maka penggunaan memory relatif lebih kecil sehingga prosesnya dapat dilakukan relatif lebih cepat.

Pemilihan ground truth serta data citra sengaja dipilih dari metode supervised sebelumnya. Tujuannya adalah untuk mengevaluasi seberapa besar perubahan hasil alpha matte metode supervised sebelum dimodifikasi dan sesudah diubah menjadi otomatis. Hasilnya terbukti dengan menunjukkan hasil nilai MAE maksimum 0,336 pada data citra Face dimana secara visual masih dapat ditoleransi.

\section{KESIMPULAN}

Pada penelitian ini memperkenalkan metodologi baru mengenai image matting dengan merubah motode supervised menjadi unsupervised. Penentuan scribbles sebagai constraint pada metode supervised matting yang ditentukan dari akuisisi foreground dan background berbasis fitur DCT secara otomatis. Penentuan jumlah parameter blok tetangga pada DCT, besaran threshold dan jumlah klaster pada k-means yang ideal ditentukan oleh varian data pada citra. Hasil perbandingan alpha matte dari penelitian yang telah dilakukan dengan metode supervised hanya berbeda maksimum sebesar 0,4 detik dari sisi kecepatan dan 0,336 pada skor MAE dan hal ini masih dapat ditoleransi secara visual.

\section{DAFTAR PUSTAKA}

AKSOY, Y. et al. (2018) 'Semantic soft segmentation', ACM Transactions on Graphics, 37(4), pp. 1-13. doi: 10.1145/3197517.3201275.

CHO, D. et al. (2016) 'Automatic Trimap Generation and Consistent Matting for Light-Field Images', IEEE Transactions on Pattern Analysis and Machine Intelligence, PP(99), pp. 1-14. doi: 10.1109/TPAMI.2016.2606397.

CHO, H.-W. et al. (2017) 'Image Matting for Automatic Target Recognition', IEEE Transactions on Aerospace and Electronic Systems, 13(9), pp. 1-1. doi: 10.1109/TAES.2017.2690529.

EISEMANN, M., WOLF, J. AND MAGNOR, M. (2009) 'Spectral video matting', Proc. $V M V, 11$.

GRADY, L. et al. (2005) 'Random walks for interactive alpha-matting', Proceedings of VIIP, 2005, pp. 423-429. Available at: http://cs.tum.edu/fileadmin/user_upload/Le hrstuehle/Lehrstuhl_XV/Research/Publicati ons/2005/VIIP05.pdf. 
554 Jurnal Teknologi Informasi dan Ilmu Komputer (JTIIK), Vol. 7, No. 3, Juni 2020, hlm. 547-554

KOESHARDIANTO, M. (2016) 'Video Object Extraction Using Feature Matching Based on Nonlocal Matting', Conference proceeding: International Seminar on Intelligent Technology and Its Application, (July), p. 201.

LEVIN, A., LISCHINSKI, D. AND WEISS, Y. (2008) 'A closed-form solution to natural image matting', Pami, 30(2), pp. 228-42. doi: 10.1109/TPAMI.2007.1177.

LEVIN, A., RAV-ACHA, A. AND LISCHINSKI, D. (2008) 'Spectral matting', IEEE Transactions on Pattern Analysis and Machine Intelligence, 30(10), pp. 16991712. doi: 10.1109/TPAMI.2008.168.

LI, W. et al. (2016) 'Roto++: Accelerating Professional Rotoscoping using Shape Manifolds', ACM Transactions on Graphics, 35(4), pp. 1-14. doi: $10.1145 / 2897824.2925973$.

LONG, Z., LIU, Y. AND HAN, S. (2017) 'Video segmentation based on strong target constrained video saliency', 2017 2nd International Conference on Image, Vision and Computing, ICIVC 2017, pp. 356-360. doi: 10.1109/ICIVC.2017.7984577.

LU, Y. et al. (2016) 'Coherent Parametric Contours for Interactive Video Object Segmentation', 2016 IEEE Conference on Computer Vision and Pattern Recognition (CVPR), pp. 642650. doi: 10.1109/CVPR.2016.76.

MASHTALIR, S. AND MASHTALIR, V. (2016) 'Sequential temporal video segmentation via spatial image partitions', Proceedings of the 2016 IEEE 1st International Conference on Data Stream Mining and Processing, DSMP 2016, (August), pp. 239-242. doi: 10.1109/DSMP.2016.7583549.

MIKSIK, O. et al. (2017) 'ROAM: A rich object appearance model with application to rotoscoping', Proceedings - 30th IEEE Conference on Computer Vision and Pattern Recognition, CVPR 2017, 2017Janua(2014), pp. 7426-7434. doi: 10.1109/CVPR.2017.785.

PORTER, T. AND DUFF, T. (1984) 'Compositing digital images', ACM SIGGRAPH Computer Graphics, 18(3), pp. 253-259. doi: 10.1145/964965.808606.

ROTHER, C., KOLMOGOROV, V. AND BLAKE, A. (2004) "GrabCut": interactive foreground extraction using iterated graph cuts', ACM Transactions on Graphics, 23(3), p. 309. doi: 10.1145/1015706.1015720.

SHEN, X. et al. (2016) 'Deep automatic portrait matting', Lecture Notes in Computer Science (including subseries Lecture Notes in Artificial Intelligence and Lecture Notes in Bioinformatics), 9905 LNCS, pp. 92107. doi: 10.1007/978-3-319-46448-0_6.

SMITH, A. R. AND BLINN, J. F. (1996) 'Blue screen matting', SIGGRAPH '96 Proceedings of the 23rd annual conference on Computer graphics and interactive techniques, pp. 259-268. doi: http://dx.doi.org/10.1145/237170.237263.

SUN, J. et al. (2004) 'Poisson matting', ACM Transactions on Graphics, 23(3), p. 315. doi: $10.1145 / 1015706.1015721$.

TAN, W. et al. (2013) 'Automatic Matting of Identification Photos', in 2013 International Conference on ComputerAided Design and Computer Graphics. IEEE, pp. 387-388. doi: 10.1109/CADGraphics.2013.60.

VICAS, G. et al. (2013) 'Automatic trimap generation for digital image matting', 2013 Asia-Pacific Signal and Information Processing Association Annual Summit and Conference, APSIPA 2013. doi: 10.1109/APSIPA.2013.6694178.

WANG, J. AND COHEN, M. F. (2007) 'Image and Video Matting: A Survey', Foundations and Trends ${ }^{\circledR}$ in Computer Graphics and Vision, 3(xx), pp. 97-175. doi: $10.1561 / 0600000019$.

ZENG, Z. et al. (2017) 'Pixel Modeling Using Histograms Based on Fuzzy Partitions for Dynamic Background Subtraction', IEEE Transactions on Fuzzy Systems, 25(3), pp. 584-593.

doi: 10.1109/TFUZZ.2016.2566811.

ZHANG, Y. et al. (2015) 'An Automatic Method for Image Matting Based on Saliency Detection ^', 10, pp. 3571-3578. doi: $10.12733 /$ jcis 14117 .

ZHU, Q. et al. (2015) 'Targeting accurate object extraction from an image: A comprehensive study of natural image matting', IEEE Transactions on Neural Networks and Learning Systems, 26(2), pp. 185-207. doi: 10.1109/TNNLS.2014.2369426. 